\title{
Serum Level of Vascular Endothelial Growth Factor (VEGF) can be used to Assess Response of Radiation Therapy in Cervical Cancer
}

\author{
Kadar Serum Vascular Endothelial Growth Factor (VEGF) dapat Digunakan \\ untuk Menilai Respons Terapi Radiasi pada Kanker Serviks
}

\author{
Ferry Armanza1, Andrijono', Bambang Sutrisna ${ }^{2}$ \\ ${ }^{1}$ Division of Oncology Gynecology, \\ Department Of obstetrics and Gynecology \\ Faculty of Medicine University of Indonesia/ \\ ${ }^{2}$ Faculty of Public Health University of Indonesia \\ Dr. Cipto Mangunkusumo General Hospital \\ Jakarta
}

\begin{abstract}
Objective: To compare the sensitivity and specificity of Squamous Cell Carcinoma (SCC) and Vascular Endothelial Growth Factor (VEGF) levels to assess the response of radiation therapy.

Method: The study was conducted by the method of analytic observational cohort study in 24 patients with cervical cancer stage II-B and III-B in RSCM that met inclusion criteria. Examination of VEGF and SCC in serum samples was performed in the Prodia Laboratory Jakarta. The examination was conducted twice before and after radiation therapy. The subjects were treated by radiation therapy/ chemoradiation according to standard procedures. After the completion of radiation was declared, the response of radiation therapy was conducted by clinical assessment.
\end{abstract}

Result: Of the 24 subjects, we obtained a mean level of SCC pre-radiation was $23.43 \pm 5.84 \mathrm{ng} / \mathrm{ml}$ and post-radiation was $2.19 \pm 0.68$ $\mathrm{ng} / \mathrm{ml}$. The mean VEGF pre-radiation was $790.41 \pm 111.06 \mathrm{pg} / \mathrm{m}$ and post-radiation was $497.47 \pm 79.26 \mathrm{pg} / \mathrm{ml}$. ROC curves of each tumor marker obtained SCC pre-radiation AUC 40\%, p 0.53 (CI 0.18 0.68 ) and SCC post-radiation AUC 48.1\%, p 0.91 (CI 0.21-0,75) can not be used as a diagnostic and prognostic factors of response to radiation therapy. VEGF pre-radiation produced an AUC of $17.5 \%$, p 0.04 (CI 0.00-0.36), thus cannot be used as a prognostic factor for response to radiation therapy. VEGF after radiation produced an AUC of $92.5 \%$, p 0.01 (CI 0.81-1.00), thus can be a diagnostic factor for response to radiation therapy. VEGF post-radiation with cut-off point $614.75 \mathrm{pg} / \mathrm{ml}$ had a sensitivity $80 \%$, specificity 75\%, NDP 94.12\%, NDN 42.86\%; RKP 3.2; RKN 0.26 and accuracy $79.16 \%$ There is a significant correlation between the decrease of serum VEGF level post-radiation and a positive response of radiation therapy (p 0.01, CI 1.00-3.23).

Conclusion: Examination of VEGF levels can be used to assess the response of radiation therapy with a sensitivity of $80 \%$ and specificity of $75 \%$.

[Indones J Obstet Gynecol 2014; 2-1: 40-45]

Keywords: cervical cancer, SCC, therapeutic response, VEGF

\begin{abstract}
Abstrak
Tujuan: Penelitian ini bertujuan membandingkan sensitivitas dan spesifisitas kadar SCC dengan VEGF untuk menilai respons terapi radiasi.

Metode: Penelitian dengan metode studi kohort analitik observasional terhadap 24 subjek penelitian yaitu penderita kanker serviks stadium II-B dan III-B di RSCM yang memenuhi kriteria inklusi. Pemeriksaan VEGF dan SCC pada sampel serum dilakukan di Lab. Prodia Pusat Jakarta, sebanyak dua kali pemeriksaan yaitu sebelum dan sesudah terapi radiasi. Subjek ditatalaksana dengan terapi radiasi/kemoradiasi sesuai prosedur standar. Setelah terapi dinyatakan selesai, kemudian dilakukan penilaian respons terapi secara klinis.
\end{abstract}

Hasil: Dari 24 subjek penelitian didapatkan rerata kadar petanda tumor SCC praradiasi $23,43 \pm 5,84 \mathrm{ng} / \mathrm{ml}$ dan pascaradiasi $2,19 \pm 0,68$ $\mathrm{ng} / \mathrm{ml}$. Rerata VEGF praradiasi 790,41 $\pm 111,06 \mathrm{pg} / \mathrm{ml}$ dan pascaradiasi 497,47 \pm 79,26 pg/ml. Dari kurva ROC masing-masing petanda tumor didapatkan SCC praradiasi AUC 40\%; p 0,53 (IK 0,18-0,68) dan SCC pascaradiasi AUC 48,1\%; $p$ 0,91 (IK 0,21-0,75) tidak dapat dipakai sebagai faktor prognostik maupun diagnostik terhadap respons terapi radiasi pada kanker serviks. VEGF praradiasi AUC 17,5\%; p 0,04 (IK 0,00-0,36) tidak dapat dipakai sebagai faktor prognostik terhadap respons terapi radiasi pada kanker serviks. VEGF pascaradiasi AUC 92,5\%; 0 0,01 (IK 0,81-1,00) dapat menjadi faktor diagnostik terhadap respons terapi radiasi pada kanker serviks. VEGF pascaradiasi dengan titik potong (cut-off point) $614,75 \mathrm{pg} / \mathrm{ml}$ memiliki sensitivitas $80 \%$; spesifisitas 75\%; NDP 94,12\%; NDN 42,86\%; RKP 3,2; RKN 0,26 dan akurasi $79,16 \%$. Terdapat korelasi bermakna antara penurunan kadar serum VEGF pascaterapi dengan respons radiasi positif ( $p$ 0,01; IK 1,00-3,23).

Kesimpulan: Pemeriksaan kadar VEGF dapat digunakan untuk menilai respons terapi radiasi dengan sensitivitas $80 \%$ dan spesifisitas $75 \%$

[Maj Obstet Ginekol Indones 2014; 2-1: 40-45]

Kata kunci: kanker serviks, respons terapi, SCC, VEGF

Correspondence: Ferry Armanza. Oncology Division, Department of Obstetrics and Gynecology, Faculty of Medicine University of Indonesia, Dr. Cipto Mangunkusumo General Hospital Jakarta Indonesia. Phone: +628125121693. Email: f.armanza@gmail.com.

\section{INTRODUCTION}

Cervical cancer is the primary cancer of the cervix (cervical canal and/or portio). Cervical cancer ranks first in overall cancer incidence in Indonesian women. ${ }^{1}$ Approximately $70 \%$ of cervical cancer patients came at advanced stage ( $>$ II-B). Re- 
search by Sarika (2006) found from the 465 new cases of cervical cancer, most cases were diagnosed as stage III-B with the most common histopathology was squamous cell carcinoma. ${ }^{2}$

Primary therapy of advanced cervical cancer is radiation. But radiation therapy is known to be able to cause complications, such as fibrosis that causes stiffness in the radiated tissue. Advanced cervical cancer generally have a large tumor size and extension. Radiation therapy may not kill cancer cells in the central region. Assessment of clinical response is based solely on the findings of the response at the surface, so it will face obstacles in the face of treatment response. One method to assess treatment response is the examination of tumor markers.

SCC antigen is a tumor marker for the presence of squamous cells that produce serine protease inhibitor. Some studies found that serum SCC can be used to monitor the onset of cervical squamous cell carcinoma after primary therapy. SCC serum levels were still high and an increase after treatment showed a tumor or progressive disease. Using a cut-off value of SCC $3.0 \mathrm{ng} / \mathrm{ml}$ Strauss HG (2002) et al detect levels of serum SCC antigen pre-operative as an independent prognostic factor in squamous cell cervical cancer, both of reccurence-free and overall survival. From the analysis concluded that SCC antigen as tumor markers correlate with prognosis in operability of cervical cancer, tumor size, status of pelvic nodes, cervical stromal infiltration, and the degree of spread of the tumor into the parametrium. ${ }^{3}$

Hong JH (1998) et al who examined the levels of squamous cell carcinoma (SCC) found that levels of SCC antigen $>10 \mathrm{ng} / \mathrm{ml}$ is an independent predictor of poor prognosis in cervical cancer and can be used as a prognostic factor in selecting patients for intensive therapy. SCC levels were still high after radiation therapy is a strong predictor of treatment failure. ${ }^{4}$

Vascular endothelial growth factor (VEGF) plays an important role in tumor angiogenesis by increasing vascular permeability, endothelial cell growth, proliferation, migration and differentiation. VEGF can also facilitate the extravasation of tumor cells and then metastasize by way of destroying the tumor extracellular matrix wall by activating the proteolytic enzymes. ${ }^{5}$

Although a lot of evidence to suggest that VEGF plays a role in microinvasion at an early stage, there has been no extensive studies to assess VEGF expression as a prognostic factor in locally advanced cervical cancer, including radiation therapy outcomes. ${ }^{6,7}$

Evaluation of the expression levels of VEGF are also useful in assessing response to therapy, such as post-radical hysterectomy, chemoradiation, and even monitor the results of treatment with antiangiogenesis drugs. This research was undertaken to assess whether serum VEGF levels have prognostic value and can be used in the treatment of cervical cancer patient. ${ }^{8,9}$

As tumor markers both VEGF and SCC need to be explored to determine which one is more sensitive and specific for assessing response to radiation therapy in cervical cancer.

\section{METHODS}

This study was a cohort study, which examined the serum levels of VEGF and SCC antigen in patients with cervical cancer stage IIB - IIIB before and after radiation therapy. The objective was to determine the relationship between the serum level of VEGF and SCC with radiation therapy response and then compare the sensitivity and specificity of VEGF and SCC to the response of radiation therapy.

The study population was all cervical cancer patients who came to RSUPN Dr. Cipto Mangunkusumo Jakarta with the following inclusion criteria, clinical stage IIB-IIIB (according to FIGO) with histopathology results squamous cell carcinoma; underwent chemoradiation/radiation; does not have any other systemic diseases that affect the levels of serum SCC antigen and VEGF and has not received treatment for cancer.

Patients were managed by chemoradiation or radiation in accordance with the study protocol. After chemoradiation or radiation has completed, another venous blood sampling was taken again about 2 (two) weeks after radiation therapy completed, to examine VEGF and SCC antigen serum levels and do clinical examination to assess the response of chemoradiation therapy.

Chemoradiation or radiation therapy response is a clinical response obtained from clinical examination 1 month after chemoradiation or radiation therapy is complete, consisting of complete response, partial response, no response/stable and 
progressive. In this study, interpretation was divided into two groups of responses, positive response $=$ complete response and negative response $=$ response beside complete response.

\section{RESULTS}

The study subjects was 24 patients with advanced cervical cancer, which comprised of 9 patients stage II-B and 15 patients stage III-B. The tumor markers, Squamous Cell Carcinoma Antigen (SCC antigen) and Vascular Endothelial Growth Factor (VEGF), was measured twice, before and after radiation. The mean level of SCC pre-radiation was $23.43 \pm 5.84 \mathrm{ng} / \mathrm{ml}$ and post-radiation was $2.19 \pm$ $0.68 \mathrm{ng} / \mathrm{ml}$, and the mean level of VEGF pre-radiation was $790.41 \pm 111.06 \mathrm{pg} / \mathrm{ml}$ and post-radiation was $497.47 \pm 79.26 \mathrm{pg} / \mathrm{ml}$.

Measurement of tumor markers pre-radiation was performed to assess whether the SCC and VEGF could be used as a prognostic factor of response to radiation therapy. While the post-radiation was examined to assess whether the SCC and VEGF have diagnostic value to replace the clinical judgement that had been done before. Based on measurements using ROC curves, we obtained respectively SCC tumor markers and VEGF for therapeutic response. (Table 1)

Table 1. Results of ROC Curves of Tumor Markers and Response of Radiation Therapy

\begin{tabular}{lccc}
\hline \multicolumn{1}{c}{ Tumor markers } & AUC (\%) & p & CI 95\% \\
\hline SCC: & & & \\
Pre-radiation & 40.0 & 0.53 & $0.18-0.68$ \\
Post-radiation & 48.1 & 0.91 & $0.21-0.75$ \\
VEGF: & & & \\
Pre-radiation & 17.5 & 0.04 & $0.00-0.36$ \\
Post-radiation & 92.5 & 0.01 & $0.81-1.00$ \\
\hline \hline
\end{tabular}

AUC: area under curve

VEGF post-radiation with AUC $92.5 \%$ results, show that VEGF levels are excellent (AUC> 90\%) to be used as a diagnostic factor in diagnosing response of radiation therapy in cervical cancer with p: 0.01 (CI: 0.81 - 1.00). (Fig. I)

To get the cut-off point of serum VEGF levels after radiation, we made a graphof VEGF sensitivity and specificity values. (Fig. II)
Post radiation serum VEGF levels at 614.75 $\mathrm{pg} / \mathrm{ml}$ had a highest sensitivity and specificity values, with sensitivity $80 \%$ and specificity $75 \%$. According to the $2 \times 2$ table with a value of 614.75 $\mathrm{pg} / \mathrm{ml}$ as the cut-off point on the response of radiation therapy, we obtained the following results. (Table 2)

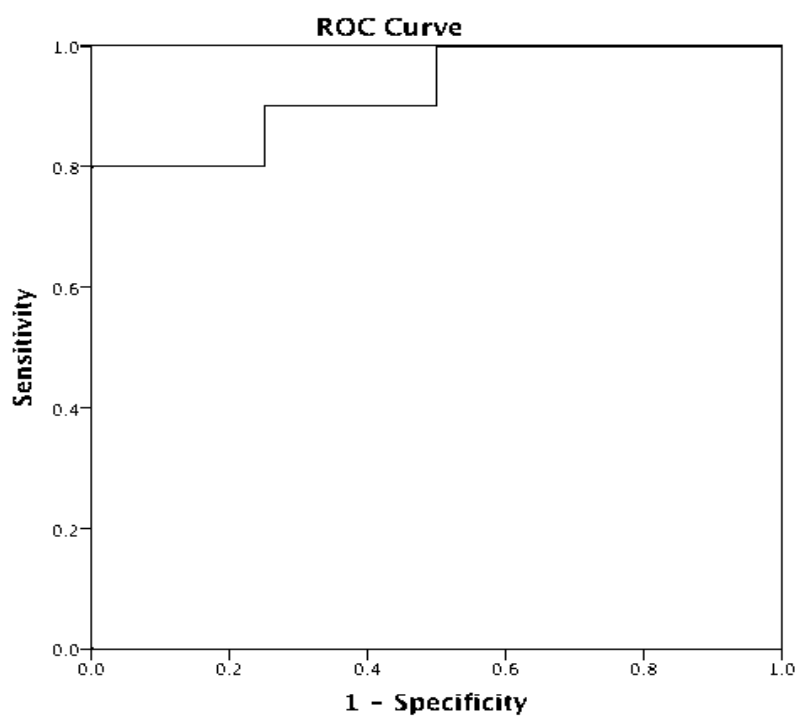

Figure 1. ROC Curve of VEGF Serum Levels in Postradiation Patients.

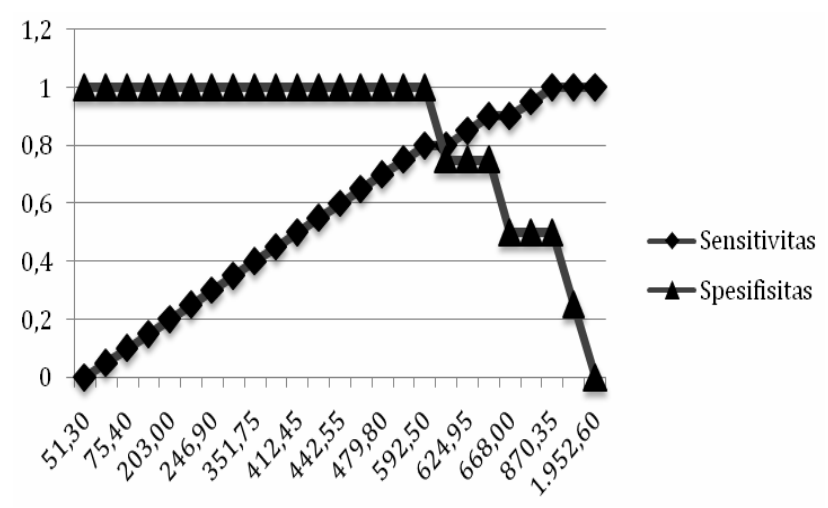

Figure 2. Cut-off Value from Sensitivity and Specificity of VEGF Levels in Post-Radiation Patients. 
Table 2. Diagnostic Value of VEGF (pg/ml) Post-Radiation and Response of Radiation Therapy.

\begin{tabular}{lccccc}
\hline \hline \multirow{2}{*}{$\begin{array}{c}\text { VEGF } \\
\text { value }\end{array}$} & \multicolumn{4}{c}{ Response of therapy } & \multirow{2}{*}{ Total } \\
\cline { 2 - 5 } & Positive & (\%) & Negative & (\%) & \\
\hline$\leq 614.75$ & 16 & 94.1 & 1 & 5.9 & 17 \\
$>614.75$ & 4 & 57.1 & 3 & 42.9 & 7 \\
\hline Total & 20 & 83.3 & 4 & 16.7 & 24 \\
\hline \hline
\end{tabular}

From the table above, the value obtained sensitivity $80 \%$, specificity $75 \%$, positive predictive value (PPV) 94.12\%, negative predictive value (NPV) $42.86 \%$, positive likelihood ratio (PLR) 3.2; negative likelihood ratio (NLR) 0.26 and accuracy $79.16 \%$.

Table 3 below shows the trend of up and down inboth serum tumor markers SCC and VEGF for therapeutic response. radiation can not be used to assess the response to radiation therapy in cervical cancer. The SCC levels reached $48.1 \%$ AUC after radiation with p: 0.91 (CI: 0.21 to 0.75 ) indicating that the SCC also can not substitute the clinical assessment of therapeutic response.

VEGF as tumor markers was also measured before and after radiation. VEGF results obtained preradiation covers only AUC 17.5\%, although the p: 0.04 (CI: $0.00-0.36$ ), as same as SCC, can not be used for assessing response to radiation therapy in cervical cancer. But VEGF post-radiation with AUC 92.5\% results, show that VEGF levels are excellent (AUC> 90\%) to be used as a diagnostic factor in diagnosing response of radiation therapy in cervical cancer with p: 0.01 (CI: $0.81-1.00$ ).

Hong JH (1998) et al examined the levels of squamous cell carcinoma (SCC) and found that le-

Table 3. Classification of Tumor Markers pre and Post Radiation and Therapeutic Response.

\begin{tabular}{|c|c|c|c|c|c|c|c|}
\hline \multirow{2}{*}{ Tumor markers } & \multicolumn{4}{|c|}{ Response of radiation therapy } & \multirow{2}{*}{$\mathbf{R R}$} & \multirow{2}{*}{ CI 95\% } & \multirow{2}{*}{$\mathbf{p}$} \\
\hline & Pos & (\%) & Neg & (\%) & & & \\
\hline \multicolumn{8}{|l|}{ SCC: } \\
\hline - Increase & 18 & 85 & 3 & 14.3 & 1.29 & $0.57-2.92$ & 0.44 \\
\hline - Decrease & 2 & 66.6 & 1 & 33.3 & & & \\
\hline \multicolumn{8}{|l|}{ VEGF: } \\
\hline - Increase & 15 & 100 & 0 & 0 & 1.80 & $1.00-3.23$ & 0.01 \\
\hline - Decrease & 5 & 55.6 & 4 & 44.4 & & & \\
\hline
\end{tabular}

It appears that the decline in serum levels of SCC from pre to post-radiation did not correlate with a positive response ( $\mathrm{p} \mathrm{0.44;}$ CI 0.57 to 2.92). While the decline in serum levels of VEGF in pre and postradiation therapy correlated with a positive response ( $\mathrm{p} 0.01$, CI 1.00 to 3.23).

\section{DISCUSSION}

Based on the pathology report in 2002, cervical cancer ranks first out of 10 cases of most cancers in both men and women and cancer in women only, with a total of 2532 cases. ${ }^{10}$ From the results of tumor markers measurements, it appears that the SCC tumor markers can not be used to assess response of radiation therapy. SCC pre-radiation levels reached only $40 \%$ AUC with p: 0.53 (CI: 0.18 to 0.68 ). These results indicate that the SCC pre- vels of SCC antigen $>10 \mathrm{ng} / \mathrm{ml}$ was an independent predictor of poor prognosis in cervical cancer, and could be used as a prognostic factor in selecting patients for intensive therapy. High levels of SCC antigen after radiation therapy was a strong predictor of treatment failure. ${ }^{4}$

Some studies find that serum SCC antigen can be used to monitor the incidence of cervical squamous cell carcinoma after primary therapy. SCC antigen serum levels which remains high or even increase after treatment showed a tumor or progressive disease. $3,11,12$

Radiation therapy is the primary treatment modality in invasive cervical cancer and can achieve satisfactory results in patients with early stage. While in patients with advanced stage therapeutic modalities are still many failures. Preliminary re- 
search conducted by Hong JH et al (1998) showed that there is a failure rate of $30 \%$ in patients with squamous cell carcinoma of the cervix with large lesions (bulky) stage IB-IIA and IIB after definitive radiation therapy, and will increase to $50 \%$ in patients with stage III. 3,4,7

Evaluation of the expression levels of VEGF are also useful in assessing therapeutic response, such as post-radical hysterectomy, chemoradiation, and even monitor the results of treatment with antiangiogenesis drugs. 7,8

Serum levels of VEGF post-radiation with AUC 92.5\% results, show that VEGF levels are excellent (AUC > 90\%) to be used as a diagnostic factor in diagnosing response of radiation therapy in cervical cancer with p: 0.01 (CI: $0.81-1.00$ ).

Cheng WF get a mean (median) intra-tumoral VEGF protein in patients with cervical cancer was $180 \mathrm{pg} / \mathrm{mg}$, whereas in normal tissue $0 \mathrm{pg} / \mathrm{mg}$. Large lesions $>4 \mathrm{~cm}$ than $<4 \mathrm{~cm}$ (1030 compared to 118). Limfo-vascular invasion than not (568 compared to 118) and patients with lymph-nodes metastasis than without metastasis $(795.5$ compared to $121 \mathrm{pg} / \mathrm{mg}$ ). Over-expression of VEGF obtained from immuno-histochemical examination of $10 / 20(50 \%)$ in cases with metastatic nodes, while the nodes without metastasis at $16 / 84$ with $\mathrm{p}=$ 0.002 .13

In this study, analysis of ROC curve and sensitivity and specificity graphs showed that VEGF levels of $614.75 \mathrm{pg} / \mathrm{ml}$ had a highest sensitivity (80\%) and specificity $(75 \%)$. The results suggest that serum VEGF levels after radiation with a cut-off $614.75 \mathrm{pg} / \mathrm{ml}$ can be used to diagnose the response of radiation therapy in cervical cancer, as mention from the values of sensitivity, specificity, PPV, NPV and sufficient accuracy, although the value of PLR $3.2(<10)$ and NLR $0.26(>0.1)$ is still inadequate.

Hansgen et al which examined serum VEGF in 42 patients with locally advanced (FIGO II-IV) squamous cell cervical cancer who were treated with radiation, found that the concentration of VEGF did not correlate with tumor stage. Comparison of VEGF levels with clinical outcome after 6 months of therapy with patients obtained a complete response occurred significantly decreased levels of VEGF (304 pg/ml \pm 188 ) compared to patients with symptoms of tumor $(892 \mathrm{pg} / \mathrm{ml} \pm 756$, $\mathrm{p}<0.0005$ ). Thus concluded that high serum VEGF levels before therapy associated with poor res- ponse to radiation therapy in locally advanced cervical cancer. ${ }^{14-16}$

This study also found that the reduction in VEGF serum levels pre and post-radiation were associated with a positive treatment response ( $\mathrm{p} 0.01, \mathrm{CI}$ 1.00 to 3.23). Thus if serum VEGF decrease after radiation therapy, the therapeutic response will be positive.

Loncaster et alexamined 100 patients with locally advanced cervical cancer (IB large lesions up to IIIB), which consisted of 94 squamous cell carcinomas, 5 adenocarcinomas and 1 adenosquamous carcinoma, found that there is no correlation between VEGF expression with disease stage, tumor differentiation, patient age and tumor radiosensitivity. In survival analysis, VEGF expression was an independent prognostic factor of the most significant $(p=0.001){ }^{6,13-17}$

This study suggests that serum VEGF levels post radiation can be used to be a diagnostic factor for response of radiation therapy in advanced cervical cancer with AUC 92.5\%, p 0.01 (CI: 0.81 to 1.00 ). VEGF serum levels with cut-off $614.75 \mathrm{pg} / \mathrm{ml}$ had a sensitivity of $80 \%$, specificity $75 \%$, PPV $94.12 \%$, NPV 42.86\%, PLR 3.2, NLR 0.26 and accuracy $79.16 \%$. And there is a significant correlation between the decrease in serum VEGF levels after radiation therapy with a positive response of radiation therapy (p 0.01, CI 1.00 to 3.23).

\section{CONCLUSION}

Examination of VEGF levels can be used to assess the response of radiation therapy with a cut off point of $614.75 \mathrm{pg} / \mathrm{ml}$, with high sensitivity (80\%) and specificity $(75 \%)$. There is also a significant correlation between the decrease in serum VEGF levels after radiation therapy with a positive response of radiation therapy.

\section{REFERENCES}

1. Andrijono. Kanker serviks uteri. Sinopsis Kanker Ginekologi. 3 ed. Jakarta: Pustaka Spirit; 2009: 59.

2. Sarika DT. Korelasi stadium dengan usia penderita kanker serviks di Departemen Patologi Anatomik RSCM tahun 2006. http://lontar.ui.ac.id/opac/themes/libri2/detail.jsp? id=123616\&lokasi=lokal

3. Strauss HG, Laban C, Lautenschlager C, Buchmann J, Schneider I, Koelbl H. SCC antigen in the serum as an independent prognostic factor in operable squamous cell carcinoma of the cervix. Eur J Cancer. 2002; 38(15): 1987-91.

4. Hong JH, Tsai CS, Chang JT, Wang CC, Lai CH, Lee SP, et al. 
The prognostic significance of pre- and posttreatment SCC levels in patients with squamous cell carcinoma of the cervix treated by radiotherapy. Int J Radiat Oncol Biol Phys. 1998; 41(4): 823-30.

5. Clauss M. Molecular biology of the VEGF and the VEGF receptor family. Semin Thromb Hemost. 2000; 26: 561-70.

6. Loncaster JA, Cooper RA, Logue JP, Davidson SE, Hunter RD, West CML. Vascular endothelial growth factor (VEGF) espression is a prognostic factor for radiotherapy outcome in advanced carcinoma of the cervix. Bri J Cancer. 2000; 83(5): 620-5.

7. Tandle A, Blazer DG, III, Libutti SK. Antiangiogenic gene therapy of cancer: recent developments. J Transl Med. 2004; 2(1): 22.

8. Libutti SK, Feldman AL. Antiangiogenic gene therapy. In: Lattime EC, Gerson SL, editors. Gene therapy of cancer: translational approaches from preclinical studies to clinical implementation. $2^{\text {nd }}$ ed. San Diego: Academic Press; 2002: 405-15.

9. Brem S. Angiogenesis and Cancer Control: From Concept to Therapeutic Trial. Cancer Control. 1999; 6(5): 436-58.

10. Aziz MF. Gynecological cancer in Indonesia. J Gynecol Oncol. 2009; 20(1): 8-10.

11. Ngan HYS, Cheng GTS, Yeung WSB, Wong LC, Ma HK. The prognostic value of TPA and SCC in squamous cell carcinoma of the cervix. Gynecol Oncol. 1994; 52: 63-8.
12. Duk JM, Groenier KH, De Bruijn HWA, Hollema H, Ten Hoor KA, Van der Zee AGJ, et al. Pretreatment serum squamous cell carcinoma antigen: a newly identified prognostic factor in early-stage cervical carcinoma. J Clin Oncol. 1996; 14: 111-8.

13. Cheng WF, Chen CA, Lee CN, Chen TM, Hsieh FJ, Hsieh CY. Vascular endothelial growth factor in cervical carcinoma. Obstet Gynecol. 1999; 93(5): 761-4.

14. Bachtiary B, Selzer E, Knocke TH, Potter R, Obermair A. Serum VEGF levels in patients undergoing primary radiotherapy for cervical cancer: impact on progression-free survival. Cancer Letters. 2002; 179: 197-203.

15. Hansgen G, Becker A, Hintner I, Dunst J. Vascular Endothelial Growth Factor (VEGF) in sera of patients with cervical cancer and the impact of platelets. Cancer cell biology and angiogenesis. 1999: 107.

16. Choi CH, Song SY, Choi JJ et al. Prognostic significance of VEGF expression in patients with bulky cervical carcinoma undergoing neoadjuvant chemotherapy. BMC Cancer. 2008; 8: 295.

17. Zusterzeel PLM, Span PN, Dijksterhuis MGK, Thomas CMG, Sweep FCGJ, Massuger LAFG. Serum vascular endothelial growth factor: a prognostic factor in cervical cancer. J Cancer Res Clin Oncol. 2009; 135: 283-90. 